\title{
Presidential Rhetoric on Foreign Crises: George W. Bush on Georgia and Barack Obama on Ukraine
}

\begin{abstract}
This article offers a critique of the rhetorical responses of President George W. Bush to the 2008 Russia-Georgia conflict and of President Barack Obama to the 2014 Russia-Ukraine conflict. Its central objective is to identify parallels and differences between the situations calling for presidential rhetoric on the crises in Georgia and Ukraine and determine how the president's reactions to the conflicts were similar or different, judging the responses against Theodore Otto Windt, Jr.'s analytical framework for foreign crisis rhetoric.
\end{abstract}

Key words: George W. Bush, Barack Obama, 2008 Russia-Georgia conflict, 2014 RussiaUkraine conflict, rhetoric of foreign crisis

\section{Introduction}

On August 7, 2008, Georgia and Russia entered into an armed conflict in Georgia's two separatist regions of Abkhazia and South Ossetia. Narratives on who initiated the war differ. Georgian authorities maintain that Russia attacked Georgian civilians in South Ossetia and forced Georgia to respond, while Russia holds that Georgian forces launched an offensive against Russian peacekeepers stationed in the region and gave Russia a reason for military action. Five days into the war, Georgia was on the defensive in the conflict. Russia took control of the territory of Georgia's regions of South Ossetia and Abkhazia. It devastated Georgian infrastructure, vessels, and airports and destroyed Georgian military bases, industries, and economic assets. A preliminary cease fire and a peace plan were announced on August 12, following which Russia and Georgia agreed to end hostilities and withdraw troops to positions they had held prior to the war. Russia's violations of the plan's provisions led to a follow-up ceasefire agreement negotiated on September 8. Despite the renewed call for withdrawal of all forces from conflict areas, Russian troops have continued to stay in Abkhazia and South Ossetia. 
A somewhat similar scenario developed on February 27, 2014 when Russia and Ukraine started an armed conflict on the Crimean Peninsula in southern Ukraine and the eastern Ukrainian regions of Donetsk, Luhansk, and Kharkiv. Within days of the conflict, Ukraine was on the defensive. Russian-backed forces took control of the peninsula and held a referendum by which Crimea approved secession from Ukraine and annexation into the Russian Federation. Donetsk and Luhansk also declared independence after referendums. Fighting in the two regions intensified and a new front opened up in eastern Ukraine. Over the course of the war, two ceasefires between Ukraine and the pro-Russian rebels were signed. The September 5, 2014 agreement was broken within days and the standing February 12, 2015 agreement, which provided for an end of hostilities and Ukrainian government control of the conflict zone has been continuously violated. Fighting between government forces and pro-Russian separatists in the regions of Donetsk and Luhansk continues.

This article analyzes the two conflicts in a comparative perspective, contrasting President George W. Bush's reaction to Russia's war with Georgia and President Barack Obama's response to Russia's invasion of Ukraine. This analysis is useful for two basic reasons. First, there has been a considerable amount of literature published on Bush's and Obama's European foreign policy, yet limited amount of research has investigated Bush's handling of the Georgia-Russia conflict and Obama's dealing of the Ukraine-Russia conflict. A review of existing scholarship, focusing specifically on crisis and rhetoric, revealed that there has been little analysis of Obama's discourse on the Ukrainian crisis and no discussion about Bush's discourse on the Georgia crisis. In addition, no study has been identified which asked whether Bush's discourse on Georgia and Obama's discourse on Ukraine represent the genre of foreign crisis rhetoric.

Second, the choice of Bush and the Georgian crisis and of Obama and the Ukrainian crisis as examples of American responses to instances of Russia's military adventurism in the post-Cold War era is appropriate given the precedents that Bush and Obama offered for future presidents to follow. As previous research has established, one president's handling of a foreign crisis influences another president's management of a crisis. In 1991, lessons were drawn from the Vietnam War, just as they were in 2002 from the Persian Gulf War (Hess 188). In this article, it is argued that in 2014 the US reaction to Russia's war with Ukraine drew from the US response to Russia's war with Georgia in 2008. Obama built a case against Russia for invasion of Ukraine upon Bush's case made against Russia for intervention in Georgia. Moreover, it is claimed that both presidents' responses adhered to the American convention of foreign crisis rhetoric but Obama's reaction was different in purpose, tone, and focus. To understand future presidents' efforts to effectively address Russia's interventions/invasions of its neighboring countries, past instances need to be examined. Risks involved in Russia's pattern of geopolitical power play make an examination of Bush's and Obama's reactions to the Georgian and Ukrainian conflicts, respectively, within a framework of foreign crisis rhetoric, a significant one.

The data in this analysis is drawn from two sources: George W. Bush's remarks on the situation in Georgia delivered on August 11, 2008 in the Rose Garden at the White House, Washington, D. C., and Barack Obama's remarks on the situation in 
Ukraine from February 28, 2014 made in the James S. Brady Press Briefing Room at the White House, Washington, D. C. In each case, the president's first official statement regarding the relevant conflict has been selected for analysis. There is an assumption in the selection of the above material that the initial reaction to a foreign crisis situation is a defining feature of the president's discourse. The immediate response is most telling of what the president thinks of the situation and how he wants to approach it. It is a rough indication of the substance and style of the statements that will follow.

The article traces parallels and differences between the two statements in three phases. First, it compares the rhetorical situations calling for foreign crisis rhetoric on the conflicts in Georgia and Ukraine. It discusses the context for US reactions, considering matters of geopolitics, US relations with Russia, the presidents' philosophies of foreign policy making, and national and international reactions to the conflicts. Second, the article contrasts the presidents' reactions for arguments that make up the American convention of presidential foreign crisis rhetoric as defined by Theodore Otto Windt, Jr.'s international crisis genre, measuring the utterances against the type's characteristics of statement of facts, narration of events, and references to morality. Third, the article considers the effects of the responses in terms of achieving the goals defined by the genre in the context of media reactions. The rhetorical effect is discussed to suggest rhetorical precedent or formula set for future presidents to follow.

\section{Background}

American perceptions of Russia's role in the conflict situations, the character of bilateral relations, the principles and values that guided the presidents' foreign policy making in general and developing relations with Russia in particular, and the responses from major political decision makers at home and abroad constitute the backdrop against which Bush's and Obama's rhetoric on the Georgian conflict and the Ukrainian conflict, respectively, can be understood. An analysis of the circumstances under which the Georgian and Ukrainian conflicts developed has shown that the situations calling for the US presidents' responses were similar in many aspects. In the cases of both Georgia and Ukraine, Russia's military action was based on the defense of its citizens and interests abroad. The implicit consideration for its use of force was to destabilize the regions, exercise control through them, and prevent expansion of NATO and the EU into the territories. The pressure tactics used to extend influence over the regions were comparable. Russia established legal ties with the governments in the breakaway regions, conferred Russian citizenship on the residents, and escalated the conflicts by moving its troops beyond the conflict zones. Although the approach was different - in the case of Georgia, Russia admitted that it was a party to the conflict and conceded the use of its military forces, while in the case of Ukraine, it insisted that it was not a belligerent force and denied a military presence in the conflict - the goals and means of reaching them were largely the same.

Similarities can also be drawn between the state of US-Russia relations in 2008 and 2014. Before the Russia-Georgia war, Russia disagreed with the US over its role 
in the 2003 Rose Revolution in Georgia and the 2004 Orange Revolution in Ukraine. Contentious issues included the US-led invasion of Iraq in 2003, the US withdrawal from the 1972 treaty on the limitations of the anti-ballistic missile systems, and the US announcement of plans to develop a ballistic missile defense system in Europe. Similarly, before Russia's invasion of Ukraine, Russia clashed with the US over its interference in the 2011 Russian legislative elections, the Syrian civil war, the Magnitsky Act, and the Edward Snowden case. Although the nature of the relationship between the leaders of the two powers was different - President Bush and President Dmitry Medvedev went beyond political divisions and kept friendly ties, unlike President Obama and President Vladimir Putin who put divisive issues first and never established a good rapport or developed trust for each other - the tone of mutual relations was much alike - marked by tension, conflict, and resistance to continued and sustained cooperation.

Reasons for this can be found in Bush's and Obama's philosophies and their underlying principles and values that inform the presidents' foreign policy doctrines as presented in the 2002 National Security Strategy of the United States of America and the 2010 National Security Strategy, respectively. An analysis of the documents has shown that fundamental to both presidents' worldviews was a belief in the importance of respect for and observance of human rights and freedoms. According to both Bush and Obama, the US should be committed to the spread of democracy, development of free markets, and promotion of free trade. For Bush, preemption and interventionism were considered to be the most adequate strategies to counter potential threats and enemies with force used deliberately to conduct a precise operation, eliminate a specific threat, and achieve a decisive result. For Obama, however, stability, success, and security were to be provided and protected by governments through consent, tolerance, and compromise. The use of force could be justified on humanitarian grounds and for reasons of self-defense or the defense of one nation against an aggressor. In other cases, military action was to be restrained and alternatives to violence, most preferably sanctions, were to be developed. Under the Bush administration, multilateralism was preferred over unilateralism, though the latter appeared to be an alternative when the US decided to act in defense of its interests outside of international organizations. Developing good relations among great powers was desirable and forming coalitions was necessary, but there were limits to potential partnerships with powers undergoing internal transition and democratic regime change. By contrast, under the Obama administration, international cooperation was key to handling global issues. The preferred course in an international context was to act within an integrated UN approach. American actions had to be planned on a case-by-case basis and they had to be planned on a long-term basis. By wielding shared power, the US could uphold its crucial role in the world without assuming responsibility alone.

Notwithstanding the differences in the philosophies of foreign policy making, the presidents shared the approach to developing relations with Russia. Both Bush and Obama acknowledged that America was the most powerful nation economically and militarily and referred to Russia as a partner among others. Bush called Russia a potential great power and Obama referred to Russia as a key center of influence and a strong voice in the international arena. Both presidents realized that differences still divided the US from Russia but declared the willingness to build a stable, productive, and long-term partnership based on mutual interests and respect. Both 
presidents held that Russia's weaknesses limited the opportunities for cooperation, with Bush pointing out Russia's distrust of US motives, unwillingness to transition to free market democracy, and reluctance towards backing nonproliferation of weapons of mass destruction, and Obama calling attention to Russia's issues with the rule of law, accountable government, and universal values. Finally, both presidents admitted that the character of Russia's regime remained a matter of concern, but limited measures for pushing Russia towards democracy to politics alone. Accordingly, although both Bush and Obama ensured Russia's neighbors of support for their sovereignty and territorial integrity, they both ruled out the use of force in conflicts with Russia in Georgia and in Ukraine.

Presidential decisions to limit the US response to political and economic options may be linked to the reactions of the US Congress, the American public, and major international actors. Addressing the Georgian crisis, the US Congress condemned Russia's military action, proposed to examine the causes of the conflict and to make policy recommendations with respect to the parties involved, and offered help for humanitarian needs, infrastructure reconstruction, governance, and economic recovery and development, but not for military purposes. Likewise, in the case of Ukraine, Congress condemned Russia's military violation of Ukrainian sovereignty, independence, and territorial integrity, demanded withdrawal of Russian forces, and offered support for Ukrainian democracy and economic stability but again it did not consider a military option.

Restraint in the foreign policy approach to the conflicts was also observed among the American public. Regarding the Georgian crisis, for which there is very limited polling data, interest in the issues was very low (17 per cent according to the Pew poll) ("China Olympics Attract Considerable Public Attention"). More frequent polling on the conflict in Ukraine shows that attention given to the crisis was relatively low too (30 per cent as per the CNN/ORC poll) ("CNN Poll: 59\% approve of sanctions against Russia"). Approval ratings for Obama's response to the conflict in Ukraine were split (30 per cent as per the Pew poll ("Most Say U.S. Should 'Not Get Too Involved' in Ukraine Situation"), 42 per cent according to the Washington Post/ ABC poll ("Americans support Ukraine sanctions, split on Obama performance"), 48 per cent as per the CNN/ORC poll ("CNN Poll: $59 \%$ approve of sanctions against Russia")), though a majority of Americans favored his decision to take economic and diplomatic measures against Russia (56 per cent as per the Post/ABC poll ("Americans support Ukraine sanctions, split on Obama performance") and 59 per cent according to the CNN/ORC poll ("CNN Poll: $59 \%$ approve of sanctions against Russia")) and opposed military means even if economic sanctions and diplomacy failed (56 per cent according to the Pew poll ("Most Say U.S. Should 'Not Get Too Involved' in Ukraine Situation") and between 76 and 88 per cent as per the CNN/ ORC Poll ("CNN Poll: 59\% approve of sanctions against Russia")).

The reactions of major international actors, including the EU, the UN, and NATO, may also be seen as factors related to the presidents' responses. In the case of both conflicts, the international response was limited to diplomacy and statements expressing grave concern about the situations, calling on all sides to refrain from military actions, and asking for restoration of talks between the parties concerned, with the exception of the EU playing a direct role in negotiating a ceasefire agreement in the Georgian crisis. 


\section{Analysis and Discussion}

Different typologies exist in literature regarding the characteristics of presidential foreign crisis rhetoric. Richard A. Cherwitz and Kenneth S. Zagacki (307-319), for instance, propose that presidential crisis rhetoric is of two types: consummatory crisis rhetoric and justificatory crisis rhetoric. Similarly, Bonnie J. Dow (294-303) divides presidential crisis rhetoric into two types: deliberative rhetoric and epideictic rhetoric. For this analysis, the arguments of Windt's international crisis genre will be used. Drawing on President John F. Kennedy's reaction to the 1962 Soviet military buildup in Cuba, Windt identifies three basic characteristics of foreign crisis rhetoric (52-57). First, crisis discourse affirms that the president controls the situation. He has knowledge of the old facts and recognizes that new facts have created a new situation. He calls this new situation critical, persuades that it demands decisive action, and assumes full public support for his policy. Second, crisis rhetoric presents the new facts using angel-devil interpretation. The president employs polarizing language to present the crisis in terms of a struggle between the forces of good and evil. He identifies and blames the enemy for the critical situation and attributes sinister motives to the adversary's actions. The goal of the language is to instill the fear of the enemy and arouse a sense of unity against the adversary. Third, crisis rhetoric announces the planned course of action and limits, if not eliminates, discussion of alternative proposals, demanding that public opinion fully supports the president's policy. In announcing steps to be taken to meet the crisis, the president shifts focus away from political and military aspects of the critical situation towards moral aspects. He re-contextualizes and re-frames policy implementation as an ethical issue.

In their initial response to the conflicts, both presidents Bush and Obama presented the facts of the conflict situations and expressed deep concern with reports of Russia's military actions. In sharing information with public opinion, Bush raised doubts about the accuracy of the reports, yet he explicitly called Russia's actions in Georgia an invasion. By contrast, Obama maintained reports of Russia's military advances in Ukraine to be true but withheld the definition of the advances in clear terms. Unlike Bush, he did not question the expert information he was disclosing but presented it as authoritative and reliable. He thus affirmed that the presidency was a source of information that could be trusted and depended upon. He did not determine Russia's actions but left the issue open in the interests of the parties involved. He allowed time and space for the facts to be adequately ascertained and defined. In an attempt to make their rhetoric work effectively, both presidents assigned meaning to the situations they were handling. Bush suggested that Russian actions could be interpreted as an escalation of the conflict and contradiction of its previous assurances. Obama decided on an elaborate suggestion and built an understanding of Russian military advances around the notions of destabilization of the international political scene, interference in another country's internal affairs, violation of one's commitments, disrespect for international laws, and deliberate provocation. He went beyond a plain statement of facts and moved the discussion towards dangers, repercussions, and consequences ensuing from Russia's further military actions, implying that the risks outweighed any benefits. 
Obama's preliminary rhetoric on the Ukrainian conflict shows responsible leadership and cautious judgment. It demonstrates the president's accountability for setting the US on a new course in its foreign relations. A revised interpretation of Russia's actions indicates a change in Washington's approach towards Moscow over its actions against neighboring countries. Implicit in the new reading are the lessons learned from the past. Rhetoric, which locks the situation and prevents it from moving in any constructive direction is replaced with discourse, which aims to bring the conflict closer to a resolution.

Narration of events makes clear the way in which both Bush and Obama framed their arguments. Both presidents drew contrasts between the intentions of the parties involved and both identified with the party in conflict with Russia. Bush juxtaposed Georgia's honesty in its approach to the peace process with Russia's duplicity in its international conduct. He stressed Georgia's compliance with the standards of the rule of law and Russia's violation of the norms. For Bush, Georgia was truthful and compliant; Russia was dishonest and resistant. Similarly, Obama attributed pure motives to Ukraine for its efforts to determine its own future and sinister motives to Russia for its attempt to impose its rule on an independent and sovereign country. He differentiated between the restraint and commitment to obligations with which Ukraine had handled the situation and Russia's record of actions destabilizing and aggravating the situation there. Unlike Bush, however, Obama acknowledged that Ukraine was a country with deep divisions and in major disagreement over its strategic direction and thus suggested that Russia might not be the only party to blame in the conflict. Instead of a stark either/or view of the situation, he offered a more complex understanding of the conflict, one which could serve as the point of departure for a new grasp of the reality informed by a third option.

The first line of argument, which introduces the contrast of motives into narration of facts continues to reflect the shift in Obama's rhetoric. It demonstrates a move away from language that draws on ideals, presenting conflict as a struggle between the forces of good and evil, towards discourse that focuses on the realities of the situation and considers its complexities in a pragmatic manner. It seeks to wind down the role of third parties and encourages belligerents to pursue a negotiated common course. The president's discourse does not hasten to assign blame, decide responsibility, or determine resolution. It offers a more balanced and graduated response to the situation. It avoids confrontation and seeks common ground by highlighting obvious relations.

The second line of argument, which relies on the contrast of actions builds on the first. Both presidents briefly narrated Russia's actions taken to destabilize the situations in Georgia and Ukraine and both commented on the record of Russia's relations with its neighbors. Bush stressed upon Russia's pattern of two-faced behavior towards Georgia, perpetuating the issue that had long separated the two nations, while Obama emphasized the history of economic, cultural, and military ties between Russia and Ukraine, the goal for the president being to expose the areas that had connected the two countries. Bush warned that Russia's aggressive actions against Georgia were putting at risk Russia's relations with the US and Europe, while Obama cautioned that hostile actions against Ukraine were against the interests of Ukraine, Russia, Europe, and the international community.

For its attempt at foreign crisis rhetoric, Bush's language describes the Georgian conflict in terms of a struggle of ideals between the West and Russia. American and 
European understanding about what constitutes democracy, freedom, sovereignty, and territorial integrity are presented as counter to the Russian interpretation of the concepts. Obama's crisis discourse, in turn, avoids assumptions permeating the antiRussian sentiment of the American public and represents an effort to address Russia and its role in the Ukrainian conflict beyond the difference of ideals. It presents Russia as a partner rather than an enemy and treats it as part of the international community rather than an adversary. Obama's context of realities replaces Bush's framing of ideals. Discourse that seeks opportunities for accommodation of conflicting interests takes the place of rhetoric that forecloses chances for reconciliation. Cold calculation of the costs and benefits of working on the conflict resolution with Russia rather than against it is preferred over an approach that thrives on differences and strengthens biases.

In the third line of argument, both presidents talked about conflict resolution and both mentioned steps that should be taken to meet the crises. As measures to achieve peace were discussed, Bush insisted that Russia act to end the crisis in Georgia, while Obama urged that stability in Ukraine be achieved by the people of Ukraine and that Russia join the international community to support Ukraine in its effort to determine its own future. Bush spoke with no intention of involving the US in the peace process, while Obama declared that the US was ready to act within an integrated international approach to assist a united Ukraine moving forward. Bush did not state that there would be any consequences for Russia in case it did not reverse the course it appeared to be on, while Obama made it clear that Russia would suffer if it took hostile actions against its neighbor. Finally, Bush placed the issue of conflict resolution in a political context, while Obama provided moral weight to the problem, the essence of which was the right to self-determination. The president suggested that the conflict was a test for Ukraine's pursuit of democracy, for Russia's restraint in its response to its neighbor's effort to stabilize the country, forge a new government, and conduct elections, and for the US' commitment to support and stand for the principles of independence, sovereignty, and territorial integrity.

Thus, Bush's argument stays on the level of rhetoric, one in which the president addresses a problem and recommends action to deal with it. The perception created is that the US will not engage in any form of intervention and will not influence Russia regarding its foreign policy. The Georgian crisis is presented as a struggle of ideals but, ideals aside, a military involvement is ruled out and other measures do not seem to be enough to deny Russia reaching its goals. Obama's argument, in turn, operates on the level of principles, which provides a strategic orientation in line with the president's understanding of America's reduced traditional global role. The fate of Ukraine will not be determined by one party only. Rather, it is a matter of shared responsibility. US military action is not considered but political, diplomatic, and economic pressure options are discussed. The conflict represents an opportunity for all parties to rise up to the challenge of revised regional roles, with the belligerents having the final word in conflict resolution and the US upholding its legal and moral obligations.

Transforming rhetoric into a particular policy, Bush took steps towards demonstrating US support for Georgia. He froze a US-Russia civil nuclear cooperation agreement and withdrew support for Russia's attempt to join the World Trade Organization. The first phase of a one-billion-dollar economic support package was 
made available and American forces were sent to Georgia to keep lines of communication and transport open for the delivery of humanitarian aid and emergency relief. While the troops were not deployed for combat, it was hoped that their presence in Georgia alone would deter further Russian military activities and ensure that Russia would fully honor the ceasefire conditions and completely withdraw from the country. This was not, however, the case. Russian forces continued to violate the peace agreement and keep troops in the breakaway areas. Countering criticism that the US reaction over Georgia was insufficient and ineffective, Bush officials made claims that the administration did take strong moves. It was maintained that the US sent warships to the Black Sea and airlifted Georgian combat troops from Afghanistan back to Georgia. Reports have shown, however, that the ships sent to Georgia carried emergency relief commodities, that international military forces in the Black Sea had been in place before the conflict in Georgia began, that Georgian military troops airlifted from Iraq not from Afghanistan, trained in counterinsurgency operations, not combined arms operations, and went into combat after Russian forces had turned the Georgian army back and destroyed much of the country.

While the Obama administration also faced criticism for its handling of Russia, its actions appeared to match the president's statements. In March 2018, Obama signed three executive orders, which imposed political and economic costs on Russia for the situation in Ukraine. On March 6, he announced sanctions blocking the property and suspended entry into the US of persons considered to be responsible for, or complicit in, activities that undermined democratic processes or institutions in Ukraine. On March 17, he targeted sanctions against named officials who held influential positions in the Russian government and were responsible for the deteriorating situation in Ukraine. On March 20, he levied sanctions against both high-level Russian officials and associates of President Putin as well as major sections of the Russian economy. While it was one thing to impose sanctions on Russia, it was quite another to make Russia bend under the strain of the measures. Holding a referendum on the independence of the Republic of Crimea from Ukraine by a pro-Russian government on March 16, signing a bill to join Crimea into the Russian Federation by President Putin on March 18, and completing the expulsion of the Ukrainian military from the Crimean Peninsula by Russian forces on March 22 were already signs that the sanctions were not having any immediate impact in terms of Russia's actions in Ukraine. While Washington insisted that the measures were substantial, they did not pressure Moscow to change course.

Explaining Bush's response to the situation in Georgia, there are at least two issues in this respect that should be mentioned: the end of the president's term of office and the US financial situation. In August 2008, Bush was an outgoing president serving his final year in office. With a record of serious setbacks in his domestic policy and foreign affairs, he did not have many options for influencing Russia over its behavior in Georgia. Moreover, during his previous five years in office, US relations with Russia had significantly deteriorated. Putting sanctions in place over Georgia would only further strain the already troubled relationship so it made sense for Bush not to aggravate the situation and keep it as it was until the new incoming president took office. Furthermore, in August 2008 the US was in the middle of a financial crash. A disruption in financial markets that had already been hurting the US financial system for a year was pushing the country into recession. As events 
of September 2008 showed, what appeared to be only a financial disruption transformed into a global financial crisis. The situation demanded government intervention and challenged the administration to put domestic issues first.

What appears to be Obama's stronger response to the Ukrainian crisis can be traced to at least two sources: Russia's outright aggression and Europe's overt support. In the case of Ukraine, Russia was the only party responsible for the conflict and its actions were widely considered to be a flagrant violation of Russia's international commitments and laws. EU member states agreed to diplomatic measures, including a cancellation of the next G-8 meeting and EU-Russia summit as well as a suspension of Russia's participation in the G-8 group and of negotiations over Russia's joining the Organization for Economic Co-operation and Development and the International Energy Agency. In addition, the EU took restrictive measures, including travel and financial sanctions on persons and entities involved in actions against Ukraine's territorial integrity and sovereignty. The fact that US-Russian relations had been at their worst since Obama took office and a reset of the relationship between the two powers had never happened only facilitated the reaction.

\section{Conclusion}

The aim of this article was to analyze President Bush's response to Russia's war with Georgia and President Obama's response to Russia's invasion of Ukraine in a comparative perspective. For the analysis, the arguments of Windt's international crisis genre were used. The responses were examined in three phases: first, the situations calling for foreign crisis rhetoric on the conflicts in Georgia and Ukraine were studied for parallels and differences between matters of geopolitics, US relations with Russia, the presidents' philosophies of foreign policy making, and national and international reactions to the conflicts; second, the arguments that make up the American convention of presidential foreign crisis rhetoric were analyzed for stability or change in the use of the foreign crisis genre; third, the effects of the responses were discussed for rhetorical precedent or formula set for future presidents to follow.

The current analysis has shown that the presidents' responses were designed under similar circumstances. Shared were the administrations' perceptions of Russia's role in the conflict situations, the tone of US-Russia relations, the presidents' approaches to developing relations with Russia, and the reactions of national and international players. The analysis has also found that the presidents' responses adhered to the American convention of foreign crisis rhetoric: both presidents presented the facts of the conflict situations, both introduced the contrast of motives and actions into the narration of facts, and both discussed conflict resolution and steps that should be taken to meet the crises. Differences between the reactions were in purpose, tone, and focus. Obama's goal was to seek solutions to the conflict rather than only present the reasons that caused it. His reaction was conciliatory and cooperative in tone rather than provocative or confrontational. It was considerate of the complexities of the conflict situation rather than limited to an either/or view of the problem. It was elevated to the level of principles that guided the president's political behavior rather than kept on the level of rhetoric that failed to be transformed into particular political performance. 
One last finding to emerge from this analysis has been the rhetorical effect of the presidents' responses. Acknowledging the methodological problems involved in the attempt to measure the impact of presidential rhetoric on the public, this analysis has not assessed the effects of the reactions on the audiences. Instead, it has intended to evaluate whether the presidents' responses to the conflicts were successful in terms of achieving the goals defined by the genre. An analysis of media reactions has shown that Bush's remarks on the situation in Georgia did not perform its functions. The Washington Post found the president's statement to be "having little impact on Russia" (Finn) and to be revealing of his "impotence" and consequently of "his personal loss of stature" and "diminished American authority on the world stage" (Froomkin). In the same vein, The New York Times stressed that Bush's warnings underscored "the limits of Western influence over Russia" (Bernard et al.) and The Wall Street Journal emphasized that his reaction expressed "The limited ability of [the] administration to protect Georgia" and "little more than rhetorical support" (Solomon). Although the tone of the remarks was described as "stern" (DeYoung) and "the strongest ... to date" (Cooper) it was noted that the president "made no mention of any potential consequences" (DeYoung) for Russia and found it difficult to "push back" and "adjust to a new geopolitical game" (Cooper). As an Associated Press article stated: "The Russian Bear [was] back, and the United States [did] not seem to be able to do much about it" (Gearan).

Media reactions to Obama's remarks on the situation in Ukraine have indicated that the president's statement did not perform its functions either, though reactions were mixed. The Washington Post criticized the president for making "no mention of consequences other than international 'condemnation' and unspecified 'costs'" and for failing to "demand that all Russian forces - regular and irregular - be withdrawn from all parts of Crimea outside the Sevastopol naval base and that Moscow recognize the authority of the Kiev government in the region" (Editorial Board). The newspaper argued that "Obama [had] things entirely wrong." The Ukrainian crisis, it held, was "about Russia and whether the West [had] the will and ability to keep Europe free and whole. Every president since George H. W. Bush [had] been committed to and [had] succeeded in that objective. Obama [might] be the first to fail" (Rubin). The New York Times was less critical when it commented that the president's warning conveyed his "effort to preclude a full-scale military escalation" as well as "limited options to respond to an intervention" (Herszenhorn et al.). Similarly, The Wall Street Journal observed that Obama had few options to challenge Russia on Ukraine, though his statement conveyed a shift to a sterner tone with Moscow and old tensions in mutual relations (Solomon).

Although the analysis of the rhetorical effect of the presidents' remarks in the context of media responses illustrates both speakers' failure to make their statements work effectively, examination of what the presidents said and how they said it is important for understanding how US presidents address instances of Russia's military adventurism and how one president's reaction holds lessons for another president's response. Neither the Georgian conflict nor the Ukrainian one held good options for maneuverability. Yet, while Bush merely reported on the situation, Obama attempted to react to it. It can be argued that his reaction was not noticeable enough but it cannot be denied that it marked a shift in approach towards Russia's interventions/invasions of its neighboring countries. Moreover, it can be 
hoped that it laid the foundation for future presidents to take a firmer stand and bring a more forceful case against Russia if/when it violates international laws and commitments again.

The limitations of the article preclude making definitive judgment of Obama's response. The analysis has covered the president's immediate rhetoric and actions and the exact impact of the reaction to the situation could be possible to determine only after an examination of follow-up discourse and policies. Obama's successor's decision to either continue and toughen the language and policies towards Russia or transform Washington's approach towards Moscow could also be an indication of the president's relative success or failure in responding to the crisis in terms of setting a rhetorical formula for other presidents to follow. Further research could usefully explore how the Obama administration continued to develop its relations with Russia and whether its rhetoric matched its actions. It could as well explore whether it managed to invite the next administration, that of President Donald Trump, to follow the pattern of pressuring Moscow regarding its international behavior. While the constraints and exigencies of the situation largely determine the form and content of presidential rhetoric, the predecessor's performance is the point of departure for the successor's rhetorical and political course direction.

\section{References}

"Americans support Ukraine sanctions, split on Obama performance." Washington Post, 2014, https:/ / www.washingtonpost.com/page/2010-2019/WashingtonPost/2014/03/11/ National-Politics/Polling/release_304.xml?tid=a_mcntx, last accessed 15 April 2019.

“China Olympics Attract Considerable Public Attention." Pew Research Center, 2008, http:// www.people-press.org/2008/08/14/china-olympics-attract-considerable-public-attention/, last accessed 15 April 2019.

“CNN Poll: 59\% approve of sanctions against Russia." CNN, 2014, http://politicalticker. blogs.cnn.com/2014/03/10/cnn-poll-59-approve-of-sanctions-against-russia/, last accessed 15 April 2019.

"Most Say U.S. Should 'Not Get Too Involved' in Ukraine Situation." Pew Research Center, 2014, http://www.people-press.org/2014/03/11/most-say-u-s-should-not-get-too-involved-in-ukraine-situation/, last accessed 15 April 2019.

"National Security Strategy." National Security Strategy Archive, 2010, http:/ /nssarchive.us/ national-security-strategy-2010/, last accessed 15 April 2019.

"The National Security Strategy of the United States of America." National Security Strategy Archive, 2002, http:/ / nssarchive.us/national-security-strategy-2010/, last accessed 15 April 2019.

Barnard, Mason. “A New World Order." Harvard International Review, 36 (4), 2015, pp. 18-19.

Bush, George. "Remarks on the Situation in Georgia. August 11, 2008." The American Presidency Project, 2008, http:/ /www.presidency.ucsb.edu/ws/index.php?pid=78058\&st=\&st1=, last accessed 15 April 2019.

Cherwitz, Richard. A. and Zagacki, Kenneth S. "Consummatory versus Justificatory Crisis Rhetoric." Western Journal of Speech Communication, 50 (4), 1986, pp. 307-324, https:/ / doi. org/10.1080/10570318609374240.

Cooper, Helene. "Russia Steps Up Its Push; West Faces Tough Choices.” New York Times, 2008, https://www.nytimes.com/2008/08/12/world/europe/12diplo.html?ref=todayspaper, last accessed 15 April 2019. 
DeYoung, Karen. “Bush Questions Moscow's Motives." Washington Post, 2008, http:// www.washingtonpost.com/wp-dyn/content/article/2008/08/11/AR2008081100752. html?hpid=topnews, last accessed 15 April 2019.

Dow, Bonnie. J. “The Function of Epideictic and Deliberative Strategies in Presidential Crisis Rhetoric." Western Journal of Speech Communication, 53 (3), 1989, pp. 294-310, https:/ / doi. org/10.1080/10570318909374308.

Editorial Board. "Condemnation isn't enough for Russian actions in Crimea." Washington Post, 2014, https://www.washingtonpost.com/opinions/condemnation-isnt-enoughfor-russian-actions-in-crimea/2014/02/28/7b93b7c0-a09d-11e3-9ba6-800d1192d08b_story.html?utm_term=.43b841448019, last accessed 15 April 2019.

Finn, Peter. "Georgia Retreats, Pleads for Truce; U.S. Condemns Russian Onslaught." Washington Post, 2008, http:/ / www.washingtonpost.com/wp-dyn/content/article/2008/08/10/ AR2008081000267.html, last accessed 15 April 2019.

Froomkin, Dam. “Bush's Georgian Betrayal." Washington Post, 2008, http://busharchive. froomkin.com/BL2008081101093_pf.htm, last accessed 15 April 2019.

Gearan, Anne. "US seems unable to stop Russia." Associated Press, 2008, http:/ / archive.boston.com/news/world/europe/articles/2008/08/12/us_seems_unable_to_stop_russia/, last accessed 15 April 2019.

Herszenhorn, David M., Landler, Mark, Smale, Alison. “With Military Moves Seen in Ukraine, Obama Warns Russia." New York Times, 2014, https:/ /www.nytimes.com/2014/03/01/ world/europe/ukraine.html, last accessed 15 April 2019.

Hess, Gary R. "Presidents and the Congressional War Resolutions of 1991 and 2002." Political Science Quarterly, 121 (1), 2006, pp. 93-118.

Obama, Barack. "Remarks on the Situation in Ukraine. February 28, 2014." The American Presidency Project, 2014, http://www.presidency.ucsb.edu/ws/index.php?pid=104756 \&st=\&st1=, last accessed 15 April 2019.

Rubin, Jennifer. “Who lost Ukraine?" Washington Post, 2014, https:/ /www.washingtonpost. com/blogs/right-turn/wp/2014/02/28/who-lost-ukraine/ ?utm_term=.255ecd3cc61d, last accessed 15 April 2019.

Solomon, Jay. "Bush's Waning Term Gives Adversaries Time to Maneuver." The Wall Street Journal, 2008, https://www.wsj.com/articles/SB121842560025829095?mod=special_ page_campaign2008_leftbox, last accessed 15 April 2019.

Solomon, Jay. “Obama Has Few Options to Challenge Russia on Ukraine." The Wall Street Journal, 2014, https://www.wsj.com/articles/obama-has-few-options-to-challenge-russia-on-ukraine-1393632653?tesla=y, last accessed 15 April 2019.

Windt, Theodore Otto, Jr. Presidents and Protesters: Political Rhetoric in the 1960s. University of Alabama Press, 1990. 